\title{
Audit Committee Financial Expertise: Antidote for Financial Reporting Quality in Nigeria?
}

\author{
Ojeka, Stephen Aanu (Ph.D)
}

Department of Accounting, College of Business and Social Sciences, Covenant University Email: stephen.ojeka@covenantuniversity.edu.ng; stojeka@yahoo.com

lyoha, Francis Odianonsen (Ph.D)

Department of Accounting, College of Business and Social Sciences, Covenant University Email: iyoha.francis@covenantuniversity.edu.ng; iyohafrancis@yahoo.co.uk

\author{
Asaolu, Taiwo (Ph.D) \\ Department of Management and Accounting, Obafemi Awolowo University, Ile-Ife \\ Email: twasaolu@yahoo.co.uk
}

\section{Doi:10.5901/mjss.2015.v6n1p136}

\section{Abstract}

Audit committee financial expertise is vital to the quality of financial reporting. This study empirically investigates the impact of audit committee financial expertise on the quality of financial reporting. The financial reporting quality was measured by reliability (total accrual quality) and relevance (audit report lag). Fifteen money deposit banks were selected and data was collected for the period (2003-2012). Analyses were carried out using Correlation, Ordinary Least Square and Panel Lest Square. The study found, after controlling for firm size, audit type, age of firm, audit committee meeting and audit committee size, that, audit committee financial expertise showed a negative coefficient for total accrual quality and audit report lag. This means financial expertise has a positive significant impact on financial reporting quality in Nigeria. The study, therefore, recommends that more attention should be given to the financial expertise of directors being recommended to the audit committee.

Keywords: Audit Committee, Financial Reporting Quality, Money Deposit Banks, Nigeria

\section{Introduction}

Audit committees, as corporate governance mechanisms play central role in the financial monitoring of firms and also provide oversight roles over accounting policies and judgments, as well as on the quality of the overall financial statements (Kevin, 2009; Blue Ribbon Committee 1999; Security and Exchange Commission Code (SEC), 2011). However, the audit committees in Nigeria especially in the banking sector (which is the most regulated sector in Nigeria) have not been seen to have demonstrated enough capacity as a result of financial scandals that often been experienced in the sector. According to Ojeka, lyoha and Obigbemi (2014), the series of events had serious devastating effect on stakeholders in terms of losses in their investments. Therefore, the trust which investors had on the credibility of the report presented by the management of companies could no longer be sustained. As a result, regulators have been increasingly concerned about the effectiveness of audit committees in monitoring corporate financial reporting in the Nigerian banking sector. Thus, there has been agitation by various stakeholders for the review of corporate governance structures and mechanisms of which the audit committees stand as the most important mechanism (Owolabi and Ogbechie, 2010).

Following the agitations to review the structures of corporate governance in Nigeria and in view of the importance attached to the institution of effective corporate governance, the Federal Government of Nigeria, through regulatory agencies have come up with institutional arrangements to protect investors in Nigeria (Kajola, 2008). The first attempt to provide for audit committee effectiveness was contained in Company and Allied Matters Act (CAMA) CAP C20, Law of the Federal Republic of Nigeria (LFN) $2004 \mathrm{Sec}$. 359. The second attempt was contained in the Code of Corporate Governance best practices issued by the Securities and Exchange Commission (SEC) in November, 2003. These two provisions failed to address the issue of audit committees in terms of financial expertise and hence failed to ensure 
quality financial reporting. The failure resulted in incessant reports that bordered on financial misappropriations which led to the removal of CEOs in some Nigerian banks (Ojeka, Kanu and Owolabi, 2013).

This, therefore, necessitated the apex Capital Market regulator (the Security and Exchange Commission) to review the Code of Corporate Governance to enhance the effectiveness of audit committees (Egwuatu, 2010). The extant SEC Code which came into operation in 2011 requires the audit committee of the board to ensure the constitution of a suitably skilled committee with members possessing basic financial literacy and the ability to read financial statements (KPMG, 2011). To this end, the Code provides that at least one of the members of the audit committee should have knowledge of accounting or financial management (SEC Code, 2011). The question that arises from the above position is whether the provisions for audit committee financial expertise can assist audit committees in ensuring quality financial reporting.

Although a few empirical studies have been undertaken on audit committee effectiveness and financial performance in the context of developing nations (see Mohammed \& Oladele, 2008; Owolabi, et al., 2010; Ofo, 2010; Adelopo, 2010; Ojeka, Kanu \& Owolabi, 2013; Uwuigbe, 2013; Ojeka, lyoha \& Obigbemi, 2014), none of these studies considered audit committee financial expertise as a useful resource in the audit committee assignment. The objective of this paper, therefore, is to evaluate the influence of audit committee financial expertise on the quality financial report within the banking sector in Nigeria.

The rest of the paper is structured into four parts. Part 2 discusses the literature and hypothesis development and part 3, the methodology. Part 4 discusses the analysis and implications of findings while part 5 is the conclusion and recommendations.

\section{Literature Review and Hypothesis Development}

The audit committee plays a central role in the financial monitoring of a firm (Kevin, 2009). It also acts in a manner that will provide oversight roles over accounting policies and judgments, as well as the quality of the overall financial statements (Blue Ribbon Committee (1999); Security and Exchange Commission Code (SEC), 2011). The SEC (2011) maintained that, to carry out the assigned tasks of monitoring financial reporting diligently, it will require significant accounting sophistication. That is, it would involve assessing the reasonableness of complex financial matters such as the company's accounting reserves, and management's handling of proposed audit adjustments suggested by the external auditors (DeFond, Hann, \& Hu, 2005). Audit committee is one mechanism available to the board of directors to limit conflicts of interest between managers and stockholders (Menon \& William, 1994). The wide adoption of the formation of audit committees around the world suggests the importance of an audit committee as a governance mechanism (Saidin, 2007). According to Cadbury Report (1992), audit committees would be important governance mechanisms that would protect the interests of the shareholders and ensure transparent reporting and improve audit quality.

This committee consists of three shareholders' representatives and three independent non-executive directors as spelt out in Nigeria's Company and Allied Matters Act (2004) with at least one qualifying as a financial expert (Sarbanes Oxley Act, 2002; Security and Exchange Commission Code, 2003). The membership of an audit committee, particularly the characteristics of its members, has been viewed as a determinant of audit committee effectiveness (Lindsell, 1992; Kalbers \& Fogarty, 1993; DeZoort, 1998).

According to DeZoort and Salterio (2001), the effectiveness of an audit committee is likely to be affected by its members' collective characteristics of being qualified and well informed, with a majority of independent members who meet frequently and have the authority to protect stakeholder interests through their diligent oversight efforts. This is where the audit committee financial expertise comes in. However, the audit committee has not shown the required ability to be able to provide the required financial oversight as evident in the financial recession, experienced especially in the Nigerian banking sector which led to the removal of some bank CEOs.

This scenario led to the criticisms of the audit committee for their inability to perform the oversight function over the company's financial activities properly. The question therefore, is that, can the audit committee give what they don't have?. Nigeria, as a developing country, has not demonstrated enough drive to empower the audit committee in what is needed to perform credibly especially in the banking sector which is the most regulated sector. The financial expertise of the audit committee in Nigeria has left much to be desired. It would appear that much emphasis has been placed on the 'politics' of appointment into the committee rather than on the skill and financial expertise of the individuals until the 2011 SEC Code. This supports the assertion of Okpara (2000) that board members are picked from the pool of high-profiled retired senior military officers and civil servants without expertise in basic finance and business operations.

The major stock exchanges in the world, for instance the New York Stock Exchange (NYSE), National Association of Securities Dealers Automated Quotation System (NASDAQ) and American Stock Exchange (AMEX) now require that 
audit committee members be able to read and understand financial statement (Bill, 2006). Adesiyan (2010) argued that, access can only be gained to what the executive directors provide. Therefore, the need to have an audit committee with financial expertise cannot be over-emphasized. As noted in extant literature, for instance, Abbott, Parker and Peters (2004); Abbott, Parker, Peters and Raghunandan (2003); Farber (2005); Carcello and Neal (2003), DeFond, et al., (2005), Lee et al. (2004); Anderson, Mansi and Reeb (2004) and Dhaliwal, Naiker \& Navissi, (2007) document lower instances of earnings restatements, higher demand for audit services and lower occurrence of financial fraud in firms with financial expertise in audit committees. Based on the foregoing, the following hypothesis is proposed-

$\mathrm{H}_{0}$ Audit committee financial expertise has no significant impact on the quality of financial reporting in the Nigerian banking sector.

\section{Research Methods}

The focus of the study is on the money-deposit banks in Nigeria. The population of the study comprises the 18 listed banks on the Nigerian Stock Exchange between the period of 2003-2011. However, the sample is made up banks that were listed and active on the Nigerian Stock Exchange (between January, 2003 and December, 2011). As a result, 15 firms were selected based on the availability of the financial statements.

For the purpose of testing the hypotheses stated, the use of Panel Least Square i.e. Least Square Dummy Variable (LSDV) was used. The study also pooled the time series and cross sectional data in testing the hypothesis stated using the OLS regression. In addition, the quality of financial reporting was decomposed into 'relevance' and 'reliability'. 'Relevance' was measured by calculating interval of days between the balance sheet closing date and the signed date of the auditor's report stated in the annual report ( lyoha, 2010). The second quality of financial reporting is 'Reliability' which is proxied by accrual quality. Schipper (1989); Burilovich and Kattelus (1997) posited that, accounting accruals remains the favored instrument for earning management because they are easy for the management to manipulate.

The accrual quality is calculated by adopting the formula used by (Bhattacharya, Daouk \& Welker 2003; Leuz, Nandan \& Wysocki, 2003; lyoha, 2010). The total accrual method adopted by these studies has been argued by McNicholas (2000) as flexible and allows for control of corporate governance and external audit attributes as additional variables. Therefore, a positive index of accrual quality suggests that the firm is engaging in income decreasing strategies and a negative accrual index indicates income increasing strategies. That is, the higher the index of accruals, the poorer the quality of financial reporting and the closer the index to zero, the better is the quality of financial reporting.

Table 3.1: Variables' Measurement/Description

\begin{tabular}{|c|c|c|}
\hline Names of Variables & Acronym & Measurement \\
\hline \multicolumn{3}{|l|}{ Dependent Variables } \\
\hline $\begin{array}{l}\text { Reliability (Total Accrual } \\
\text { Quality) }\end{array}$ & TAQ & See Appendix \\
\hline Relevance (Audit Report Lag) & ADLAG & $\begin{array}{l}\text { Interval of days between the balance sheet closing date and the signed } \\
\text { date of the auditor's report stated in the annual report }\end{array}$ \\
\hline \multicolumn{3}{|l|}{ Independent Variables } \\
\hline $\begin{array}{l}\text { Audit Committee Financial } \\
\text { Expertise }\end{array}$ & FEXP & $\begin{array}{l}\text { The number of individuals on the audit committee who are experienced in } \\
\text { financially literate }\end{array}$ \\
\hline \multicolumn{3}{|l|}{ Control Variables } \\
\hline Audit Committee Size & ACSIZE & Whether the audit committee has three or more members \\
\hline Firm Size & FMSIZE & $\begin{array}{l}\text { This is measured as the book value of the total asset of the firm at the end } \\
\text { of financial year }\end{array}$ \\
\hline Audit Committee Meetings & ACMT & Whether the audit committee meets at least 4 times annually \\
\hline Firm Age & FAGE & $\begin{array}{l}\text { This is measured as the number of years the company has been publicly } \\
\text { traded }\end{array}$ \\
\hline Audit Type & AUDTYP & Type of auditor the firm is engaging \\
\hline
\end{tabular}

Adapted from Ojeka, lyoha and Obigbemi (2014) 
Model Specification

To achieve the objective of this study, the following mathematical equations were developed to investigate the influence of audit committee financial expertise on the quality of financial report in the Nigerian banking.

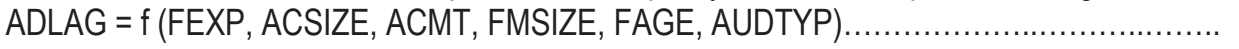

$T A Q=f(F E X P, A C S I Z E, A C M T, F M S I Z E, F A G E$, AUDTYP $)$

Models 1 and 2 can now be stated explicitly in the following form:

$A D L A G_{i t}=\lambda_{0}+\lambda_{1} F_{E X P_{i t}+\lambda_{2} A C S I Z E_{i t}+\lambda_{3} A C M T}+\lambda_{4} F_{\text {FMSIZE }}+\lambda_{5} F_{\text {FMAGE }}+\lambda_{6} A U D T Y P_{i t}+\mu_{\text {it }}$

TAQ $Q_{i t}=\beta_{0}+\beta_{1}$FEXP $_{\text {it }}+\beta_{2}$ ACSIZE $_{i t}+\beta_{3}$ ACMT $_{\text {it }}+\beta_{4}$ FMSIZE $_{i t}+\beta_{5}$ FMAGE $_{\text {it }}+\beta_{6}$ AUDTYP $_{\text {it }}+\mu_{\text {it }} \ldots$

Using LSDV (Panel Data Estimation), equation 3 in model $A$ above becomes:

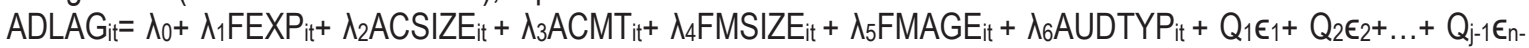
$1+\mu_{\text {it }}$

and equation 4 in model $A$ above also becomes:

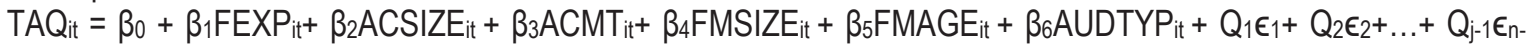
$1+\mu_{\text {it }}$

Where $j=n=18$

The parameters of the model are such that:

$\beta_{1}, \beta_{2} \ldots \ldots \ldots \ldots \ldots \ldots \beta_{6}>0 ; \beta_{7}<0$

$\alpha_{1}, \alpha_{2} \ldots \ldots \ldots \ldots \ldots . . . . . . . . \alpha_{6}>0 ; \alpha_{7}<0$

and

$Q_{1}, Q_{2} \ldots \ldots \ldots \ldots \ldots . . . . . . . . Q_{6}>0 ; \quad Q_{7}<0$

$i=1,2 \ldots \ldots .18$ and $t=1,2 \ldots \ldots 10(2003-2011)$

\section{Analysis and Presentation of Results}

This section shows the results descriptive statistics. The hypothesis was tested using ordinary least square (OLS) and the Panel data analysis.

\section{Descriptive Statistics}

Table 4.01: Banks Sampled

\begin{tabular}{|c|c|c|}
\hline Banks & No of years sampled & Years of Observation \\
\hline Access & 9 & $2003-2011$ \\
\hline Diamond & 9 & $2003-2011$ \\
\hline ECO & 9 & $2003-2011$ \\
\hline FCMB & 6 & $2006-2011$ \\
\hline First Bank & 9 & $2003-2011$ \\
\hline Fidelity & 9 & $2003-2011$ \\
\hline GTB & 9 & $2003-2011$ \\
\hline Skye & 6 & $2006-2011$ \\
\hline Stanbic IBTC & 9 & $2003-2011$ \\
\hline Sterling & 6 & $2006-2011$ \\
\hline UBA & 9 & $2003-2011$ \\
\hline Union & 9 & $2003-2011$ \\
\hline Unity & 6 & $2006-2011$ \\
\hline Wema & 9 & $2003-2011$ \\
\hline Zenith & 9 & $2003-2011$ \\
\hline TOTAL & 123 & $2003-2011$ \\
\hline
\end{tabular}

Source: Field Study (2013)

The table above shows that out of the population, only 4 banks had a sample of six years while others had a sample of nine years. The affected banks with uncompleted financial reports undertook mergers and acquisitions between 2003 and 2011. Hence, completed financial reports could not be found. 
Table 4.02: Descriptive Statistics for the Population

\begin{tabular}{|c|c|c|c|c|c|}
\hline \multicolumn{7}{|c|}{ Variables } & Mean & Max. & Min & Std.Dev & P.value \\
\hline \multicolumn{5}{|c|}{ Dependent: } & \\
\hline ADLAG & 91.36585 & 304 & 14 & 54.47247 & 0.00000 \\
\hline TAQ & -0.0173 & 0.953806 & -2.47251 & 0.289498 & 0.00000 \\
\hline \multicolumn{7}{|c|}{ Independent: } \\
\hline FIN. EXPERTISE & 0.780488 & 1 & 0.333333 & 0.199404 & 0.13386 \\
\hline Control Variables: & \multicolumn{1}{c|}{} & & \\
\hline AGE & 35.85366 & 117 & 11 & 30.65452 & 0.00051 \\
\hline AUD_MT & 0.617886 & 1 & 0 & 0.487892 & 0.00031 \\
\hline AUD_SIZE & 5.788618 & 6 & 4 & 0.547004 & 0.00000 \\
\hline AUD_TYP & 0.97561 & 1 & 0 & 0.154888 & 0.00000 \\
\hline FIRM SIZE & 543153.5 & 2463543 & 21603 & 518574.8 & 0.04038 \\
\hline OBSERVATIONS & 123 & 123 & 123 & 123 & \\
\hline
\end{tabular}

Source: Field Survey (2014)

The table above shows the descriptive statistics for the population (Banking sector). It shows that on the average the reporting lag for the banks in the sector stands at 91 days, minimum reporting days in the sector stood at 14 days which could be attributed to Zenith Bank and the maximum in the sector stood at 304 says which could be attribute to Wema Bank. It also shows that audit committee meeting is held frequently i.e. at least every quarter (0.6). Audit size for the banks stands at 6 and the major auditors of the banks are amongst the Big Four (0.9), the Big 4 auditing firms audited approximately $98 \%$ of the sample banks. In addition, accrual quality among these banks was negatively signed to indicate an income increasing strategy. The respective standard deviations also confirm that the number of reporting days is widely dispersed. All the variables i.e. dependent, independent and control variables were all significant at $1 \%, 5 \%$ and $10 \%$ levels.

Table 4.03: Relevance (Reporting days) of Financial Reporting by Banks Sampled

\begin{tabular}{|c|c|c|}
\hline Banks & Mean & Std. Deviation \\
\hline Access & 62.1111 & 24.22006 \\
\hline Diamond & 83.3333 & 24.2384 \\
\hline ECO & 113.8889 & 38.11314 \\
\hline FCMB & 110.1667 & 23.92001 \\
\hline Fidelity & 82.2222 & 21.60311 \\
\hline First & 87.6667 & 6.98212 \\
\hline GTB & 43.1111 & 32.84983 \\
\hline Skye & 102 & 60.69596 \\
\hline Stanbic IBTC & 69 & 35.84341 \\
\hline Sterling & 117.3333 & 30.34249 \\
\hline UBA & 59.2222 & 25.49401 \\
\hline Unity & 137.3333 & 79.06369 \\
\hline Union & 123.3333 & 42.05948 \\
\hline Wema & 182 & 82.93823 \\
\hline Zenith & 31.5556 & 19.70477 \\
\hline
\end{tabular}

Source: Field Survey (2014)

Table (4.03) showed the reporting lag in days of the population sample (15 banks) in this study. The minimum number of reporting lag days recorded in the banking sector was Zenith bank (14 days) while the longest number of days is recorded by Wema Bank. Quite a number of the banks within (2003-2011) released its financial report early compared to other banks but still were unable to sustain such standards for example, Access Bank. In general on the average, almost all the banks were able to meet the Security and Exchange Commission (SEC) stipulated time of 90 days and BOFIA 
statutory reporting date of 120 days except for Unity bank and Wema Bank. Zenith Bank has the lowest mean rate followed by GT Bank and the longest is recorded by WEMA Bank. The respective standard deviations also confirm that the number of reporting lag days is widely dispersed.

Table 4.04: Accrual Quality by Banks Sampled

\begin{tabular}{|c|c|c|}
\hline Variables & Mean & Std. Dev. \\
\hline Access & 0.038725564 & 0.078884 \\
\hline Diamond & -0.01158999 & 0.030577 \\
\hline ECO & 0.08725166 & 0.150425 \\
\hline Fcmb & 0.088934902 & 0.149351 \\
\hline Fidelity & 0.000678792 & 0.040913 \\
\hline First & 0.00920971 & 0.02698 \\
\hline GTB & 0.011350174 & 0.037131 \\
\hline Skye & -0.00959967 & 0.031075 \\
\hline Stanbic IBTC & -0.25965129 & 0.830402 \\
\hline Sterling & 0.003635555 & 0.014196 \\
\hline UBA & -0.13899607 & 0.290373 \\
\hline Union & -0.0451395 & 0.583981 \\
\hline Unity & 0.02734439 & 0.059879 \\
\hline Wema & -0.00378739 & 0.011485 \\
\hline Zenith & 0.001991674 & 0.007217 \\
\hline
\end{tabular}

Source: Field Survey (2014)

Table 4.04 gives the accrual quality of the sampled banks. The indicators demonstrate that some banks engage in earnings management and losses management in one form or the other. The mean accrual manipulations are 0.04 , $0.01,0.09,0.09,0.00,0.01,0.01,-0.01,-0.25,0.00,-0.14,-0.05,0.03,-0.01,0.00$ for all the banks respectively. The minimum range showed negative sign for all the banks sampled that is, at one point in time within (2003-2011) all the banks engaged in income increasing strategy. This could be the impact of 17 - man committee set up by Atedo Peterside in the year 2000 to identify the weaknesses of corporate governance practices with respect to public companies. In summary, the manipulations as revealed by statistics are income increasing and income decreasing effects because the signs of the indices are both negative and positive.

Table 4.05: Correlation Test for Independent variables

\begin{tabular}{|c|c|c|c|c|c|c|}
\hline & AGE & ACMT & AC-SIZE & AUD-TYP & FEXP & F.SIZE \\
\hline \multirow{2}{*}{ AGE } & 1 & & & & & \\
\hline & & & & & & \\
\hline \multirow{2}{*}{ ACMT } & $-350^{* \star}$ & 1 & & & & \\
\hline & 0.000 & & & & & \\
\hline \multirow{2}{*}{ AC_SIZE } & $.214^{*}$ & 0.033 & 1 & & & \\
\hline & 0.018 & 0.719 & & & & \\
\hline \multirow{2}{*}{ AUD_TYP } & 0.04 & $.201^{*}$ & -0.061 & 1 & & \\
\hline & 0.662 & 0.026 & 0.5 & & & \\
\hline \multirow{2}{*}{ FEXP } & 0.052 & 0.114 & $.222^{*}$ & $.356^{\star \star}$ & 1 & \\
\hline & 0.568 & 0.21 & 0.013 & 0.000 & & \\
\hline \multirow[t]{2}{*}{ FMSIZE } & $.344^{\star \star}$ & 0.091 & $.270^{\star \star}$ & 0.007 & 0.093 & 1 \\
\hline & 0.000 & 0.318 & 0.003 & 0.94 & 0.305 & \\
\hline
\end{tabular}

Source: Field Survey (2014) 
Table 4.05 shows the Pearson Correlation results. The results indicate that quite a number of the variables are significant $1 \%, 5 \%$ and $10 \%$ based on the Pearson's statistic. The correlation amongst the variables is not as high as 0.8 . This indicates that there is no presence of multi-collinearity amongst the variables since no correlation coefficient is greater than 0.9. According to Gujarati and Porter (2009); Hair, Black, Babin and Anderson (2010) posited 0.8 as the threshold at which multicollinearity concerns can be harmful to the regression analysis and make the reliability or the positive power of the model reduced.

\section{Ordinary Least Square (OLS) Regression Analysis}

Table 4.06: Regression Results: Whole Sample

\begin{tabular}{|c|c|c|c|}
\hline & & Financial Repo & lity Measurements \\
\hline & & 1 & 2 \\
\hline \multirow{4}{*}{ Independent Variables } & \multirow{4}{*}{ Predicted Sign } & Reliability (TAQ) & Relevance (ADLAG) \\
\hline & & Coefficient & Coefficient \\
\hline & & (t-statistics) & (t-statistics) \\
\hline & & P-value & P-value \\
\hline \multirow[t]{2}{*}{ ACFEXP } & - & $\begin{array}{c}-0.0363^{* *} \\
(-1.79) \\
0.075\end{array}$ & $\begin{array}{c}-12.584^{*} \\
(-4.4933) \\
0.062\end{array}$ \\
\hline & \multicolumn{3}{|c|}{ Control Variables } \\
\hline ACSIZE & - & $\begin{array}{c}-0.0175^{\star} \\
(-1.52) \\
0.100\end{array}$ & $\begin{array}{c}2.70564 \\
(0.296) \\
0.767\end{array}$ \\
\hline ACMT & - & $\begin{array}{c}0.0259^{* * *} \\
(2.66) \\
0.0087\end{array}$ & $\begin{array}{c}23.0703^{* *} \\
(2.16) \\
0.032\end{array}$ \\
\hline FAGE & - & $\begin{array}{c}0.0114^{*} \\
(1.65) \\
0.100\end{array}$ & $\begin{array}{c}37.8781^{* * *} \\
(4.76) \\
0.000\end{array}$ \\
\hline FSIZE & - & $\begin{array}{c}-0.0082^{* * *} \\
(-2.49) \\
0.014\end{array}$ & $\begin{array}{c}-13.6053^{\star * *} \\
(-3.01) \\
0.003\end{array}$ \\
\hline AUDTYP & - & $\begin{array}{c}-0.0062 \\
(-0.740) \\
0.460)\end{array}$ & $\begin{array}{c}-14.9113 \\
(-0.45) \\
0.615\end{array}$ \\
\hline Constant & $?$ & $\begin{array}{c}0.1900^{* *} \\
(2.12) \\
0.035\end{array}$ & $\begin{array}{c}133.2224^{* *} \\
(1.88) \\
0.061\end{array}$ \\
\hline $\begin{array}{c}\text { P-value } \\
\text { F-test } \\
\mathbf{R}^{2} \\
\text { R }^{2} \text { Adjusted } \\
\text { No of Obs. }\end{array}$ & & $\begin{array}{c}0.1066 \\
1.558 \\
0.074 \\
0.027 \\
123\end{array}$ & $\begin{array}{c}0.000 \\
4.213 \\
0.179 \\
0.136 \\
123\end{array}$ \\
\hline \multicolumn{4}{|c|}{ Keys: ${ }^{* * *},{ }^{* *},{ }^{*}$ Significant at the $1 \%, 5 \%$ and $10 \%$ levels respectively } \\
\hline
\end{tabular}

Source: Field Survey (2014)

The table 4.06 explain the overall model as valuable and helpful because the $\mathrm{F}$ statistics is significant in the equation. The F. Statistics is 4.2133 and 1.558 for timeliness/Adlag and reliability (Accrual Quality) respectively. At the same time, the p-value for TAQ and ADLAG is 0.000 and 0.1066 with an R2 of 0.179 and 0.074 respectively. Most importantly, the finding suggests that, financial expertise of the audit committee (FEXP) is negatively significant with the relevance of financial reporting. The implication of this is that the more the financial experts in the audit committee, the lower the audit 
report lag and the more the relevance of the report to users. Our result is consistent with Carcello and Neal (2000) where it was found that audit committee expertise have significant negative relationship with audit fee while Ummi and Rashidah (2011) submitted that financial expertise may reduce audit report lag.

With reference to reliability (TAQ) of the financial report, consistent with the priori expectation, financial expertise of the audit committee (FEXP) showed a negative and significant impact on reliability of financial reporting.

\section{Panel Least Square (LSDV) Regression Analysis}

Table: 4.07: Regression Results: Whole Sample

\begin{tabular}{|c|c|c|c|}
\hline & & Financial Repo & lity Measurements \\
\hline & & 1 & 2 \\
\hline \multirow{4}{*}{ Independent Variables } & \multirow{4}{*}{ Predicted Sign } & Reliability (TAQ) & Relevance (ADLAG) \\
\hline & & Coefficient & Coefficient \\
\hline & & (t-statistics) & (t-statistics) \\
\hline & & P-value & P-value \\
\hline ACFEXP & - & $\begin{array}{c}-0.1928^{\star *} \\
(-1.398) \\
0.064\end{array}$ & $\begin{array}{c}-59.4184^{* * *} \\
(-2.69) \\
0.0084\end{array}$ \\
\hline \multicolumn{4}{|c|}{ Control Variables } \\
\hline ACSIZE & - & $\begin{array}{c}-0.0274 \\
(-0.598) \\
0.551\end{array}$ & $\begin{array}{c}-0.6048 \\
(-0.08) \\
0.937\end{array}$ \\
\hline ACMT & - & $\begin{array}{c}0.1464^{*} \\
(1.67) \\
0.097\end{array}$ & $\begin{array}{l}0.4131 \\
(0.04) \\
0.967\end{array}$ \\
\hline FAGE & - & $\begin{array}{c}0.0406 \\
(0.744) \\
0.453\end{array}$ & $\begin{array}{c}43.833^{* * *} \\
(6.609) \\
0.000\end{array}$ \\
\hline FSIZE & - & $\begin{array}{c}0.0127 \\
(0.569) \\
0.570 \\
\end{array}$ & $\begin{array}{c}-40.4713^{* * *} \\
(-7.584) \\
0.000\end{array}$ \\
\hline AUDTYP & - & $\begin{array}{c}-0.1151^{* *} \\
(-2.180) \\
0.0314 \\
\end{array}$ & $\begin{array}{c}56.7259^{*} \\
(1.89) \\
0.0612 \\
\end{array}$ \\
\hline Constant & $?$ & $\begin{array}{l}0.0181 \\
(0.569) \\
0.5703\end{array}$ & $\begin{array}{c}454.329^{* *} \\
(6.11) \\
0.000\end{array}$ \\
\hline $\begin{array}{c}\text { P-value } \\
\text { F-test } \\
\mathrm{R}^{2} \\
\mathrm{R}^{2} \text { Adjusted } \\
\text { No of Obs. }\end{array}$ & & $\begin{array}{c}0.0380 \\
1.084 \\
0.1232 \\
0.0096 \\
123\end{array}$ & $\begin{array}{c}0.000 \\
7.112 \\
0.4796 \\
0.4122 \\
123 \\
\end{array}$ \\
\hline
\end{tabular}

Source: Field Survey (2014)

The panel data regression for audit committee financial expertise on the quality of financial reporting in the Nigerian banking sector as it relates to relevance is presented in table 4.07. The $R^{2}$ for relevance (ADLAG) stood at 0.4797 while that of reliability (TAQ) stood at 0.1232 which means that $48 \%$ of the variation in ADLAG and $12.3 \%$ in TAQ were explained by the model respectively. The p-values stood at 0.0000 with t-statistics of 7.112 for ADLAG and $p$-values of 0.0380 with t-statistics of 1.084 for TAQ which is significant both at $1 \% 5 \%$ and $10 \%$ respectively. The data is balanced because the fixed effect model also engaged the independent variable considered in the OLS regression model.

Therefore from table 4.07, the financial expertise (FEXP) shows a significant negative impact on the quality of 
financial reporting (relevance). It is significant at $1 \%$ level and almost at zero level and is consistent with previous results. This indicates that FEXP of the audit committee member is paramount and the most crucial in ensuring the relevance of financial reporting in the Nigerian Banking Sector. In the same vein, the assessment of the empirical result reported in the table above signify that financial expertise (FEXP) of the audit committee is negatively and significantly influence the reliability (Accrual Quality) of financial reporting $(p<0.1)$. Also it has the highest coefficient which means FEXP is the most prominent and impactful determinant of reliability of financial reporting. This is to say that, an increase in the financial expertise of the audit committee would lead to a low accrual quality. This means financial expertise of the audit committee positively influences the reliability of financial reliability and thereby advance the quality of financial reporting in the Nigerian banks. The result has a t-statistics of 1.084 and a p-value of 0.06 negatively signed and its value is significant at $10 \%$ level of significance.

This result was consistent with the a priori expectation indicating audit committee financial expertise as the most prominent and impactful determinant of preserving financial integrity and reliability of financial reporting. This confirms the position of regulators (e.g. Sarbanes Oxley Act, Nig. SEC Codes, 2011) and stakeholders in the financial sector across the world and particularly in Nigeria on the need to have financial experts in the audit committee bearing in mind the recent high profile fraudulent cases as observed in the Nigeria Banking Sector and across the world. The finding in this study with respect to audit committee financial expertise is consistent with Kalbers and Fogarty (1993); DeZoort (1997), (1998); BRC (1999); SOX, (2002); SEC Code, (2011) where it was proposed that the presence of financial experts in audit committees will assist the committee in, critically analyzing accounting policies and financial statements, identifying potential problems, and solving problems.

\section{Decision}

The result of the empirical analysis in table 4.06 showed that (Pooled OLS Regression of Financial Expertise (FEXP) with a coefficient of -12.584 and -0.036 and P-value of 0.06 and 0.07 and an overall F-statistics of 4.213 and 1.558 and pvalue of 0.0007 and 0.1066 for relevance and reliability respectively) and of the Fixed effect regression in table 4.07 (FEXP coefficient of -59.418 and -0.192 and $p$-value of 0.008 and 0.064 and an overall F-statistic of 7.112 and 1.084 and p-value of 0.000 and 0.037 for relevance and reliability respectively), the null hypothesis which stated that Audit Committee Financial Expertise has no significant impact on the quality of financial reporting in the Nigerian Banking sector cannot be uphold and is therefore rejected.

\section{Conclusion and Recommendation}

This study examined if audit committee financial expertise is an important characteristics of financial reporting quality or a necessary evil. The results as demonstrated shows that, financial skills/ intelligent is critical for audit committee members in ensuring high quality reports. From both the OLS and LSDV reports, the financial expertise shows a consistent sign and coefficient in enhancing the relevance (ADLAG) and reliability (TAQ) of the financial report in the Nigerian banking sector. Perhaps, if the audit committee members possessed sound financial expertise, the event in 2010 that led to the removal of CEOs of eight banks in Nigeria would not have happened.

The results however hint on important implication for policy makers, regulatory authorities and stakeholders on the need to improve on certain policies that can enhance productivity and good governance in Nigeria. For example, the Company and Allied Matters Act 1990 (hereafter CAMA) stipulates the composition of audit committee only in term of numbers without any provision to its effectiveness or how it can be productive. CAMA makes no mention about the financial expertise of the audit committee members which is the major factor for audit committee effectiveness. Though SEC and CBN Codes fairly addressed this issue of financial expertise of the audit committee, this is however not backed up by law. Government should therefore endeavor to incorporate audit committee governance in CAMA to become a law for listed firms in Nigeria. This is because SEC code in Nigeria does not mandate preparers of financial report to comply. It has always been like an appeal or advice for compliance without any or little attendant penalty if not adhered to.

It is worthy to note that most of audit committee members in Nigeria as presently constituted have very low capacity to understand International Financial Reporting Standard (IFRS) based financial report which they are meant to provide oversight function (Ojeka, Kanu \& Owolabi, 2014). Therefore, there is an urgent need to ensure that Nigerian audit committee members are fully equipped and fortified with financial skill and intelligent. The committee must be able to demonstrate capability to protect and add value to shareholders/stakeholders interests.

This study, though with robust results and strength, have its limitations and therefore, caution should be taken in drawing conclusions and interpreting of the result. The limitations are considered as opportunity for further research and 
advancing the body of knowledge especially in this area. First, the financial expertise is not separated into finance, accounting and supervisory expertise as few studies have done. Also, the study considered only the listed banks with complete financial report in Nigeria and lastly, the study made use of Ordinary Least Square and Panel Data Statistical techniques for the analysis. Hence, further studies could explore the decomposition of financial expertise, consider other sectors especially firms not listed.

\section{References}

Abbott, L.J., Parker, S. and Peters, G. (2004). Audit committee characteristics and restatements. Auditing: A Journal of Practice and Theory, 23 (1), 69-88

Abbott, L. J., Parker, S., Peters, G. F., \& Raghunandan, K., (2003). The association between audit committee characteristics and audit fees. Auditing: A Journal of Practice \& Theory, 22, 17- 32.

Adelopo I., (2010). Impact of corporate governance on auditor independence: a study of audit committees in UK listed companies. (Unpublished Ph.D Thesis), De Montfort University, United Kingdom

Adesiyan T. (2010,). False financial report: shareholders, audit committee refute blame. Vanguard Newspaper. Retrieved from http://www.vanguardngr.com/2010/04/false-financial-reportfalse-financial-report-shareholders-audit-committee-refute-blame/

Anderson, R., Mansi, S. \& Reeb, D. (2004). Board characteristics, accounting report integrity, and the cost of debt. Journal of Accounting and Economics, 37(3), 315-342.

Bhattacharya, Daouk \& Welker (2003) The world price of earnings opacity. Accounting Review, 78(3) 641-678

Blue Ribbon Committee (1999). Report and recommendations of the blue ribbon committee on improving the effectiveness of corporate audit committee. New York: New York Stock Exchange.

Burilovich, L., Kattelus, S., (1997). Auditors' Influence on Earnings Management: Evidence from the Alternative Minimum Tax", Journal of Applied Business Research, Vol. 13, pp. 9-22.

Cadbury Committee (1992). Report of the committee on the financial aspects of corporate governance. London, Professional Publishing Ltd.

Carcello, J. V., \& Neal, T.L. (2003a). Audit committee characteristics and auditor dismissals following" new" going-concern reports, Accounting Review, 95-117.

Carcello, J. V., \& T. L. Neal. (2000). Audit committee composition and auditor reporting. The Accounting Review, 75, 453-467.

Companies and Allied Matters Act (CAMA) (1990) is now cited as Companies and Allied Matters Act CAP C20 LFN 2004

DeFond, M., Hann, R., \& Hu, X. (2005). Does the market value financial expertise on audit committees of boards of directors? Journal of Accounting Research, 43(2), 153-193.

DeZoort, F.T. (1998). An analysis of experience effects on audit committee members' oversight judgments. Accounting Organizations and Society, 23(1), 1-21.

Dhaliwal, D.S., Naiker, V. \& Navissi, F (2008). Audit committee financial expertise, corporate governance and accruals quality: an empirical study. Revise and resubmit to Contemporary Accounting Research

Dhaliwal, D.S., Naiker, V., \& Navissi, F., (2007). Audit committee financial expertise, corporate governance and accruals quality: an empirical analysis. Working Paper, University of Arizona, University of Auckland, and Monash University.

Egwuatu, P. (2010, February 28). SEC indicts audit committees for ignorance of roles. Vanguard Newspapers.

Farber, D., (2005). Restoring trust after fraud: does corporate governance matter? The Accounting Review, 80, 539-561

Gujarati, Damodar N. and Dawn C. P. (2009) Basic Econometrics. New York, NY: McGraw-Hill Irwin.

Hair, J.F. Jr., Black, W.C, Babin, B.J. and Anderson, R.E. (2010) Multivariate Data Analysis: A Global Perspective. (7th ed.). New Jersey: Pearson Education Inc.

Iyoha, F. (2010). State agencies, industry regulations and the quality of accounting practice in Nigeria. (Unpublished Ph.D Thesis). Covenant University, Ota, Nigeria.

Kalbers, L.P., \& Fogarty, T.J., (1993). Audit committee effectiveness: an empirical investigation of the contribution of power. auditing: A Journal of Practice and Theory, 12(1), 24-49.

Kajola, S.O. (2008). Corporate governance and firm performance: the case of Nigerian listed firms. European Journal of Economics, Finance and Administrative Sciences, 14

Kevin L. (2009). Liability Exposures of Audit Committee Chairs. Retrieved 21/10/2012 from http://www.dandodiary.com/2014/04/articles/ director-and-officer-liability/liability-exposures-of-audit-committee-chairs/

KPMG Professional Service (2011): corporate governance and the new SEC code. Retrieved on 4/8/2011 from www.ng.kpmg.com

Leuz, Christian., Dhananjay Nanda, and Peter D. Wysocki, 2003, Earnings management and investor protection: an international comparison, Journal of Financial Economic, 69, 505-527.

Lee, H. Y., Mande, V., \& Ortman, R. (2004). The effect of audit committee and board of director independence on auditor resignation. Auditing: A Journal of Practice \& Theory, 23, 131-146.

Lindsell, D. (1992). Blueprint for an effective audit committee. Accountancy, 104.

McNicholas, M. (2000). Research design issues in earnings management studies. Journal of Accounting and Public Policy 19(4/5): 313345

Menon, K., \& J. Williams. (1994). The use of audit committees for monitoring. Journal of Accounting and Public Policy, 13(2), 121-139. 
Mohammed, K. and Oladele K. ( 2008), 'Corporate Governance and Firm's Performance in Nigeria', KASU Journal of Management Sciences, 1(4)

Ofo, N. (2010). An appraisal of audit committees of public companies in Nigeria. Social Science Research Network. Retrieved from http://papers.ssrn.com/sol3/papers.cfm?abstract_id=1641603\&download=yes

Ojeka, S.A., Kanu, C. and Owolabi, F. (2013), IFRS-based results and the readiness of Nigerian audit committee: the professional Accounting academic standpoint. European Journal of Accounting, Auditing and Finance Research. Vol.1 (4) pp. 1- 11.

Ojeka, S.A., Iyoha, F.O. and Obigbemi, I.F. (2014), effectiveness of audit committee and firm financial performance in Nigeria: an empirical analysis. Journal of Accounting and Auditing: Research \& Practice, vol. 2014(2014), Article ID 301176, doi:10.5171/2014. 301176

Owolabi, A and Ogbechie, C. (2010). Audit committee reports and corporate governance in Nigeria. International Journal of Critical Accounting. 2(1), 64-78

Saidin, S.F.B. (2007). Audit committee characteristics and quality of unaudited financial accounts. Dissertation retrieved 8/3/2012 from http://eprints.usm.my/7837/1/audit_committee_characteristics_and_quality_of_unaudited_financial_accounts.pdf

Schipper, K. 1989. Commentary on Earnings Management. Accounting Horizons (Vol. 3, No. 4): 91-102.

Securities and Exchange Commission (2011): Code of corporate governance in Nigeria. Retrieved from http://www.sec.gov.ng.com/ governance.htm

Ummi J.B.H. \& Rashidah, B.A.R. (2011). Audit report lag and the effectiveness of audit committee among Malaysian listed companies, International Bulletin of Business Administration. 10

Uwuigbe, O.R. (2013), 'Corporate Governance and Share Price: Evidence from Listed Firms in Nigeria', An International Multidisciplinary Journal, 7 (2), 129-143 